\title{
SCHOOL INFLUENCES ON PARENTS' ROLE BELIEFS
}

\author{
By \\ Manya C. Whitaker
}

\author{
Dissertation \\ Submitted to the Faculty of the \\ Graduate School of Vanderbilt University \\ in partial fulfillment of the requirements \\ for the degree of \\ DOCTOR OF PHILOSOPHY \\ In \\ Psychology \\ May, 2011 \\ Nashville, Tennessee
}

Approved:

Professor Kathleen Hoover-Dempsey

Professor Bethany Rittle-Johnson

Professor Georgene Troseth

Professor Claire Smrekar 
Copyright (C) 2011 by Manya C. Whitaker All Rights Reserved 
To my sweet brother, Morris "Clint" Whitaker, who was always most proud of me, no matter what life handed him 


\section{ACKNOWLEDGEMENTS}

This work would not have been possible without the continued guidance from my

advisor, Dr. Kathleen Hoover-Dempsey. She is more than a mentor; she is an advocate, a supporter, and a friend. I am forever in her debt.

I would be remiss not to mention others who cried with me, laughed with me, and stayed up late at night encouraging me when my motivation weakened: Antrameka Knight, Troy Stewart, Jamila Smith, Anita Johnson, Yah Demann, Christopher Thomas, and Jane Mantey. To those who read countless drafts and now know as much as I about parental involvement, I am grateful to you: Jason Ewart and Harold Brown.

Lastly, no one has been more important during this process than my family. To my mother, Michele Whitaker, and my father, Rocky Whitaker: you put me on the path to get me here, and you never let me stray. Thank you. 


\section{TABLE OF CONTENTS}

Page

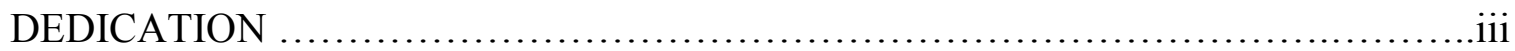

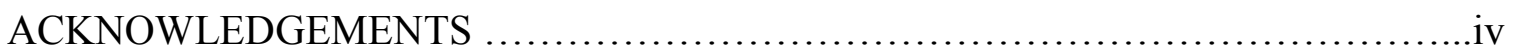

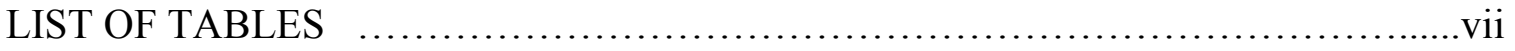

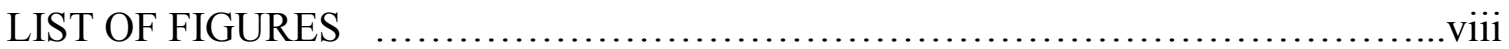

\section{Chapter}

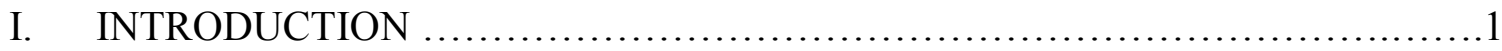

Parents' role construction for involvement.............................6

Contextual motivators to parents' involvement .........................8

General school invitations to involvement ........................8

School climate............................................. 9

Specific teacher invitations to involvement.......................9

Specific student invitations to involvement .......................10

Purpose and research questions...................................11

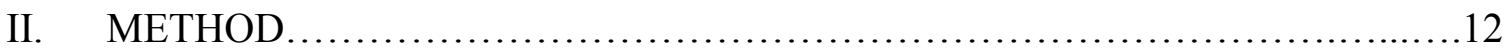

Procedures ......................................................... 12

Participants ........................................................... 14

Full sample.............................................14

Freedom middle school .....................................14

Sunrise middle school..........................................15

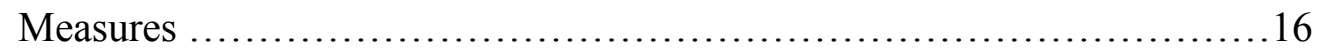

Outcome variable ............................................. 18

Experiential predictor of role beliefs............................. 18

School predictors of role beliefs............................. 19

III. RESULTS............................................................ 21

Research question 1 .................................................24

Research question 2 ..............................................28

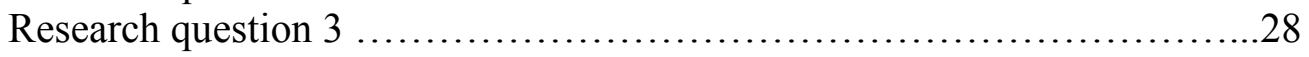

Freedom middle school .....................................29

Sunrise middle school ......................................33 


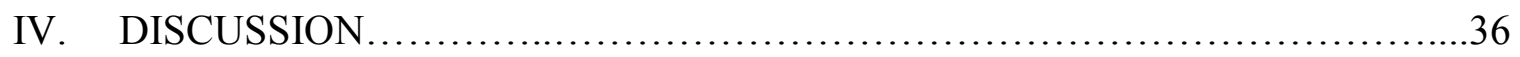

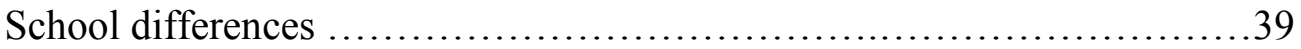

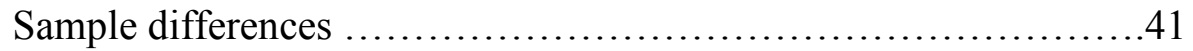

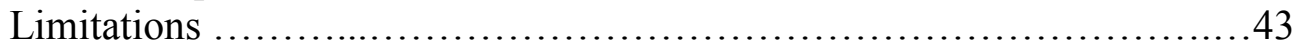

Implications for research ........................................... 44

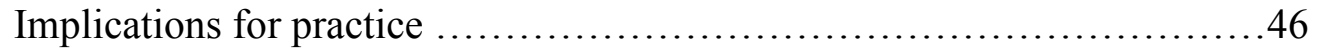

Conclusion........................................................... 47

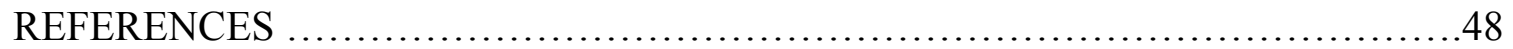




\section{LIST OF TABLES}

Table

Page

1. Summary of Demographic Statistics................................... 17

2. Descriptive Statistics and Independent Sample $t$-tests.......................23

3. Summary of Correlations for Full Sample...................................26

4. Summary of Correlations for Freedom Middle School...........................31

5. Summary of Correlations for Sunrise Middle School.........................34 


\section{LIST OF FIGURES}

Figure

Page

1. Path Analysis Map for Full Sample......................................27

2. Path Analysis Map for Freedom Middle School................................32

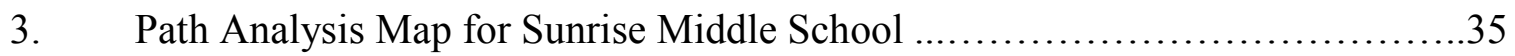




\section{CHAPTER I}

\section{INTRODUCTION}

Low-income urban students often live and attend schools in areas that are densely populated and characterized by high crime and high poverty (Lee, 1999). The schools are often old, overcrowded, and lacking financial and personnel resources when compared to suburban schools which are more likely to have newer buildings, smaller classes, qualified teachers, and up to date textbooks (Buckley, Schneider, Shang, 2005; Corcoran, 1988; Lankford, Loeb, \& Wyckoff, 2002). Further, urban schools often serve large populations of diverse students from low educated and racial minority families (Moles, 1993; Murry et al., 2004).

Students in these schools are likely to experience schools and schooling in a different context than their wealthier, more educated, or ethnic majority counterparts (Comer \& Schraft, 1995; Crane, 1996; Green, Blasik, Harshorn, \& Shatten-Jones, 2000). For example, research (e.g. Trumbell, Rothstein-Fisch, Gieendfield, \& Quiroz, 2001; Valdes, 1996) has suggested that low-income urban parents often have different beliefs about their role in their children's learning than do higher income suburban parents. These urban parents tend to believe the school is responsible for educating their children, while parents are responsible for ensuring children are prepared and equipped for school (e.g. by making sure children are rested, fed, and properly attired; e.g. Lareau, 1987). Additionally, some research (e.g. Auerbach, 2007) has suggested that urban parents also believe it is their responsibility to launch their child for success by motivating, 
encouraging, and guiding their children, and by maintaining a positive relationship with children through support and open communication with their child.

Suburban parents however, assume a more political role in their child's schooling. Many of these parents participate in school governance, through which they gain knowledge about school policies and academic opportunities pertinent to their child's learning. It is at these functions that suburban parents create relationships with school faculty and other parents that allow them to make informed decisions about their child's classroom assignment and course schedule. Suburban parents with such insight describe the educational process as a joint endeavor they share with school personnel, whose guidance they accept, but are willing to refute. In general, suburban parents often view their role as being an advocate for their children through monitoring both the student's and teachers' educational practices (Lareau, 1987).

Despite some differences in how low-income urban parents and wealthier suburban parents construe their role in their children's learning, there are notable similarities in what they do to be involved. Recent research suggests that lower income parents, like middle and upper income parents, are actively involved in their children's education. In particular, these parents help their children with homework, enroll their children in extracurricular activities, maintain high expectations, provide a quiet space for work at home, and engage community resources for additional academic help (Lawson, 2003; McKay, Atkins, Hawkins, Brown, \& Lynn, 2003; McWayne, Campos, \& Owsianik, 2008; Wong \& Hughes, 2006). Also like their suburban counterparts, many urban parents have been found to discuss the school day with their children, provide direct instruction on school assignments, monitor children's peer groups, attend parent- 
teacher conferences, and volunteer at the school (Ingram, Wolfe, \& Lieberman, 2007; Ji \& Koblinksy, 2009). In essence, these urban parents engage in many of the same involvement behaviors as wealthier parents in suburban schools, despite research findings suggesting they are less involved (Coleman, 1987; Epstein \& Dauber, 1991; KlimesDougan, 1992).

One factor that facilitates lower income urban parents' involvement in particular, is the administrative structure and functioning of the school. Research on principal leadership suggests that school demographics influence administrative decision-making pertinent to parent involvement (Hart, 1992). For example, among higher income schools in which parents are highly involved in children's learning, parents want principals who prioritize school curriculum, instructional practices, and student assessment, rather than principals who use school resources to increase parental outreach and community building (Fine, 1993; Seefeldt, Denton, Galper, \& Younoszai, 1998). Conversely, in schools serving largely low-income families with lower levels of education, parental involvement is predicted by the school's active outreach to parents and development of collaborative interpersonal relationships, as well as the school's provision of detailed suggestions for how parents can help students improve their academic performance (Simon, 2004). Hierarchical administrative structures that emphasize the school's authority (relative to parents and students) are perceived by low and high-income parents as controlling and manipulative, and may result in parents' disengagement from the school, or parents' distrust of school personnel (Griffith, 2001). These findings suggest then that urban schools hoping to increase the incidence and effectiveness of parental involvement should engage administrative approaches that prioritize relationship- 
building, and provide specific involvement opportunities for parents (Christenson, 2004; Hoover-Dempsey, Whitaker, \& Ice, 2010).

In a supportive educational context, parents' participation in their children's learning at home and school is an especially important pathway to increased student academic and social outcomes for all students (for reviews see Fan \& Chen, 2001; Henderson \& Mapp, 2002; Jeynes, 2005, 2007). Parents' active support of children's learning in all educational settings has been associated with more positive attitudes toward schools, better attendance, increased self-esteem, increased motivation to learn, higher grade point averages, and higher test scores (Desimone, 1999; Kaplan, Liu, \& Kaplan, 2001; Reynolds, 1992; Sheldon, 2007; Tan \& Goldberg, 2009; Zellman \& Waterman, 1998). Interestingly, meta-analyses focused on urban parental involvement (e.g. Jeynes, 2005, 2007) have reported stronger associations between parents' involvement behaviors and student achievement than have been found more broadly within the parental involvement literature. These findings suggest that parent involvement may be a particularly powerful avenue to decreasing the achievement gap between low-income students in urban schools, and their wealthier counterparts in suburban schools.

Because parental involvement and student achievement have been linked in urban schools serving low-income families, federal policies were created to increase the effectiveness of urban school parent involvement initiatives. For example, section 1118, Title I of the No Child Left Behind Act of 2002 outlines school district policies regarding parental involvement. Schools with at least $40 \%$ of students enrolled in the free and reduced lunch program qualify to receive Title I funds. According to this act, every 
school receiving Title I funds must have a written parent involvement policy and must effectively implement the parent policy provisions. This policy must be developed jointly with, approved by, and distributed among parents of participating children and the local community. Additionally, the Title I legislation states that schools are responsible for holding meetings for parents to discuss parent involvement policies, programs, and activities, all within flexible hours designed to accommodate working parents. The legislation also requires that Title I funds used in the creation of parent involvement opportunities should be decided upon with input from parents, and that funds may also be used to provide transportation for parents in need.

Title I policies do not describe how parental involvement initiatives are to be designed and implemented in schools. While districts and schools are required to document program development and participation, there are no direct suggestions for decisions regarding staffing, allotment of funds, or quantity of programs offered to participating parents. The absence of such directives in these areas, coupled with the absence of enforcement provisions, means that Title I schools have a lot of discretion in the extent to which guidelines are followed and parent involvement is prioritized as an essential component of school functioning and student learning. Because parent involvement has been identified as integral to decreasing the achievement gap (Green, 2001; Lee \& Bowen, 2006), it is essential that researchers, policymakers, and schools identify and support specific factors that influence parental involvement in urban schools. 


\section{Parents' Role Construction for Involvement}

Research has suggested that one factor influential in parents' decisions about becoming involved in their children's education is parents' role construction for involvement. Within the parent involvement literature, role construction refers to a parent's beliefs about what he or she is supposed to do in relation to his or her children's education (Hoover-Dempsey \& Sandler, 1995, 1997; Hoover-Dempsey, et al., 2005; Walker, Wilkins, Dallaire, Sandler, \& Hoover-Dempsey, 2005). This construct is derived primarily from role theory, which defines a role as a socially constructed set of duties, rights, obligations, and expected behaviors that correspond with particular positions in varied social contexts (Biddle, 1986; Maccoby, 1980). Biddle suggested that role acquisition involves the interaction of social and cognitive processes and thus, that roles are socially constructed. In particular, he suggested that roles are grounded in expectations, norms, attitudes, and environmental demands related to particular social factors. In the case of parents' role construction for involvement, parents' development of personal ideas about what their role in their child's learning should be is influenced by the expectations and attitudes of important others (e.g. teachers, family members, children, other parents) in the educational context.

Vygotsky (1978) and Rogoff, Paradise, Arauz, Correa-Chavez, and Angellilo (2003) elucidated the importance of the social environment in the creation and maintenance of individuals' ideas and beliefs about their roles in varied contexts. Important in this social process are interpersonal communications and collaborations between a learner and more knowledgeable others, explicit expectations and goals for the new role, and the provision of relevant, constructive feedback from important others after 
a behavior is performed. As key members in this social process, teachers and other school personnel are in a position to help parents develop and maintain effective roles in their child's schooling.

Indeed, many teachers maintain communication with parents throughout the school year regarding school events and student progress. Additionally, teachers particularly invested in parental involvement often convey involvement expectations to parents at the beginning of the school year (Pang \& Watkins, 2000) and provide parents with feedback about the effectiveness of their involvement during parent-teacher conferences, weekly phone calls, or in some cases, daily notes in students' agendas (Jones, White, Aeby, \& Benson, 1997). Similarly, students discuss their feelings and thoughts about school to parents, and relay their expectations for involvement by asking for help or inviting parents to school events. Overall, these ideas suggest that parents' role construction may be influenced or shaped by teachers, school personnel, and students as they communicate their involvement expectations to parents, work with parents to develop appropriate involvement behaviors, provide reasons for suggested involvement behaviors, and offer feedback after parents engage in involvement activities.

The present study focused on identifying the relationships between parents' role construction for involvement and theoretically grounded social motivators of involvement such as parents' perceptions of general school invitations to involvement, teacher invitations to involvement, and student invitations to involvement. In addition, the study examined the contributions of the school climate as it relates to parent involvement. In an effort to understand the contributions of previous and current schoolrelated social experiences with schools to parents' construction of their role in children's 
learning, parents' valence toward school (defined as the extent to which a parent, based on personal prior experience with schooling, is generally attracted to or repelled from school; Hoover-Dempsey, Sandler, Wilkins, \& Jones O’Connor, 2004) was also examined for potential contributions to parents' role construction for involvement.

\section{Contextual Motivators of Parental Involvement General school invitations to involvement.}

General school invitations to involvement were measured to assess the schools' communication with parents about parent involvement opportunities. Efforts made to communicate with parents through automated phone calls, school marquees, and mass mailings represent impersonal, broad involvement initiatives that are separate from the personal social interactions reflective of school climate. General school invitations to involvement often emerge in requests for parents' support and participation in schoolwide events like fundraisers, community service projects, or open-houses. They may also be incorporated in packets of information about school programs or events, school and district policies, and parental rights and responsibilities in relation to school functioning (Chrispeels \& Rivero, 2001; Epstein \& Dauber, 1991). General school invitations to involvement have not been examined extensively as a predictor of parents' involvement decisions. Role theory suggests that school members' shared expectations of parents (both within the schools and with parents) may help parents shape their understanding of their role in their children's schooling. 


\section{School climate.}

Unlike general school invitations to involvement, parents' perceptions of school climate are reflective of school practices that welcome, value, and respect parents as participants in students' education (Griffith, 2001). Moos (1979) defined school climate as the "social atmosphere of a setting or learning environment in which students and parents have different experiences, depending upon the protocols set up by the teachers and administrators" (p. 81). With regard to parent involvement, he suggested that a positive school climate allows families to participate and develop relationships with the faculty and staff as well as with other families, and encourages families to be an integral part of decision making on issues affecting their children's education. A school's climate is determined by the social interaction between parents and school personnel-which role theory suggests is critical in parents' understanding of their role.

Seefeldt et al., (1998) found that parents' perception of school climate was significant in predicting school-related involvement. Similarly, Griffith (1998) reported that the extent to which a parent feels welcome (e.g. the office staff is helpful and courteous, and teachers and principal are interested and cooperative when discussing the parent's child) predicted parents' participation in school-based involvement activities.

\section{Specific teacher invitations to involvement.}

Teacher invitations emerge in part from teachers' recognition and valuing of parents' contributions to student learning (Adams \& Christenson, 2000), and in part from teachers' responsiveness to parents' requests for specific information about how to help their students learn (Hoover-Dempsey, Bassler, \& Burrow, 1995). The importance of teachers' invitations to involvement has been supported by several investigators whose 
works suggests that teachers' invitations are among the strongest predictors of parental involvement behaviors (e.g. Desimone, 1999; Epstein \& Van Voorhis, 2001; Green \& Hoover-Dempsey, 2007; Grolnick et al., 1997; Trumbull, Rothstein-Fisch, \& Hernandez, 2003) and are also positively correlated with parents' role construction (Anderson \& Minke, 2007; Green, Walker, Hoover-Dempsey, \& Sandler, 2007; Sheldon, 2002).

\section{Specific student invitations to involvement.}

Student invitations to involvement are motivated by students' own desires for parental assistance with academic work, and for parents' attendance at school functions important to the child. Student invitations are also supported by teachers asking students to engage parents in specific, short, manageable activities at home that support, compliment, or reinforce children's school learning (Balli, Demo, \& Wedman, 1998; Epstein \& Van Voorhis, 2001). Additionally, students' school achievement may prompt more implicit parent involvement such as academic monitoring or increased parentteacher communications (Pomerantz, Grolnick, \& Price, 2005). Student invitations to involvement have consistently been found to be the most powerful predictors of parent involvement across home and school contexts and across grade levels (Anderson \& Minke, 2007; Deslandes \& Bertrand, 2005; Green et al., 2007; Hoover-Dempsey et al., 2005; Sheldon, 2002). Additionally, student invitations have been found to be predictive of parents' role construction for involvement (Auerbach, 2007). 


\section{Purpose and Research Questions}

Taken together, these findings suggest that parental role construction is important in parents' decisions about involvement, and that it often works in concert with other motivators to affect parental involvement behaviors. What we do not know is how such motivators interact to help parents develop ideas about their role in their children's learning. Further, it is also unclear if or how those ideas are shaped by the school--a social context most relevant to parents' ideas about their personal responsibility for supporting their children's learning.

This study examined if and how parents' ideas about their roles in children's learning are shaped by their prior experiences with schools (valence), and their experience of specific school practices related to parental involvement (general invitations to involvement, school climate, teacher invitations to involvement, and student invitations to involvement). Additionally, I examined how the two schools' different administrative approaches to parent involvement (parent involvement coordinator responsible versus all faculty and staff responsible) appeared to function differently in supporting parents' role beliefs.

Three research questions were investigated: 1) Across the two schools, how are parents' valence toward school, perceptions of general school invitations, perceptions of specific teacher invitations, perceptions of specific student invitations, and perceptions of school climate related to their beliefs about their role in supporting their children's education? 2) Do parents' current experiences with schools influence their role beliefs more than their prior experiences with schools? 3) Do the two schools differ significantly across study constructs and in variables influencing parents' role beliefs? 


\section{CHAPTER II}

\section{METHOD}

\section{Procedures}

Prior to the study, permission was granted by the school district to disseminate parent involvement surveys in up to three Title I middle schools. Meetings with principals yielded two willing participants in the study. The principals of each school invited me to attend a faculty meeting at the school. At both faculty meetings, I explained the study to teachers and administrative staff, passed out sample surveys, explained the benefits of the study to the school, and answered questions.

Data were collected at two time points. At the end of the 2009-2010 academic year, anonymous survey packets were given to the parent involvement coordinator at Freedom middle (pseudonym) and to the reading specialist at Sunrise middle (pseudonym) who agreed to be the primary contact for the study. Each was asked to give teachers enough packets for students in their homerooms. Each packet contained a cover letter briefly explaining the contents of the packet, a detailed informational sheet outlining the study and parents' rights to refuse participation, and the survey. Parents were instructed to send completed surveys sealed in the envelope provided by way of their child. Children who returned a completed survey were given a $\$ 5$ gift card to McDonalds. Additionally, the class(es) with the highest percentage return rate at each school were given a pizza party at the end of the semester. 
Data collection was interrupted by a natural disaster that caused both schools to be closed for three days during the 10 day data collection period. Families at both schools were affected by the disaster and at least $30 \%$ of surveys that had been returned to Sunrise were destroyed by the flooding. Freedom middle school experienced the additional reality that it had been without a principal for two months. The parent involvement coordinator reported that without the principal's presence, many teachers lacked administrative encouragement to collect surveys from students.

These occurrences necessitated a second round of data collection in the fall of the 2010-2011 academic year. To avoid duplication of data, surveys were given only to $5^{\text {th }}$ grade parents new to each school at the end of the first semester of the academic year. Instructions on the survey were changed from asking parents to respond with reference to "this school year" to asking parents to respond with reference to their experiences "thus far this school year". After a 10 day period, surveys were collected from both schools. Because parents' receipt of surveys relied upon teachers and students, it was not possible to know how many surveys actually reached parents. Thus, calculated return rates are conservative approximations. Overall, 349 surveys were returned across the two schools; a 29\% return rate. At Freedom, 204 surveys were collected; a return rate of $35 \%$. At Sunrise, 145 surveys were returned; a return rate of $24 \%$. Though lower than desirable, survey return rates in the present study were consistent with the $25 \%-35 \%$ range often reported for low-income populations in the parent involvement literature (e.g. Anderson \& Minke, 2007; Hoover-Dempsey, Bassler, \& Brissie, 1992; Tan \& Goldberg, 2009). 


\section{Participants}

\section{Full sample.}

The full sample of parents (Table 1) included $85 \%$ female respondents and was racially diverse, including Black (52\%), White (34\%), Hispanic (7\%), and Asian (4\%) respondents. Forty percent of parents reported incomes less than $\$ 20,000$, while $15 \%$ reported annual incomes over $\$ 50,000$. A small portion of the sample (10\%) reported having less than a high school diploma, while most parents in the full sample graduated from high school or obtained a GED (38\%), or had some college or vocational training (37\%). Eight percent obtained Bachelors degrees and 6\% reported having a graduate degree.

\section{Freedom middle school.}

Freedom middle school is a Title I school with 40 teachers serving students in grades 5-8. The majority of students were Black (69.7\%) with smaller percentages of White (19.3\%) and Hispanic students (9.5\%). Almost all students (90.5\%) qualified for free or reduced lunch, and $11.4 \%$ of students received special education services. In $2009,75.5 \%$ of the students tested proficient in reading and $71.4 \%$ of students were proficient in math. This school was a Title I school for over five years and consequently, had a well developed parent involvement program. Under the direction of a parent involvement coordinator, the Parent Partnership Center was responsible for school-wide involvement initiatives. Located near the entrance to the school, the Parent Partnership Center was the venue for almost all events, including parent focus groups about school improvement plans, parent education workshops that provide parents with skills directly related to their child's current learning goals, and community resource fairs. Additionally, 
every quarter, parents were invited to have lunch with their child, and to participate in a family trivia night. Parents were asked to help write the parent-teacher-student compact at the beginning of the year, and were encouraged to stay involved by the school's opendoor policies and more explicit invitations to volunteer. Efforts to communicate with parents were made through annual meetings, bi-monthly newsletters, and daily student agendas.

Parents from Freedom who returned surveys represented the larger school demographic well (Table 1). Most were mothers (86.3\%), and matched the racial breakdown of the school (68\% Black and 21\% White). There was an underrepresentation of Hispanics (4.1\%), despite the fact that surveys were sent home to Spanish speaking families in Spanish. The sample was largely low-income, with $47.6 \%$ of respondents reporting an annual income of less than $\$ 20,000$ (approximately $8 \%$ reported annual incomes over $\$ 50,000)$. Parents' report of educational attainment revealed that $13 \%$ had less than a high school education, $42 \%$ received a high school diploma or GED, 35\% had some college, $5 \%$ received a Bachelor degree, and 5\% received a graduate degree.

\section{Sunrise middle school.}

Sunrise middle school is a Title I school with 38 teachers serving students in grades 5-8. Over half of the students were White (58.5\%) and about a quarter were Black (25.9\%), with a smaller population of Hispanic students (13.7\%). Half of the students $(50.1 \%)$ qualified for free or reduced lunch, and $8.9 \%$ of students received special education services. In $2009,92.2 \%$ of the students tested proficient in reading, and $89.4 \%$ of students tested proficient in math. In accordance with federal Title I policies, administrators at this school were in the process of creating a parent involvement 
program (i.e. there was no current parent involvement program at the time of the study) and hiring a parent involvement coordinator. Parent involvement initiatives were limited to parent-teacher conferences, open house, and field day—each occurring once a semester. Efforts to contact parents were made by individual teachers or through letters sent home with students.

The sample from Sunrise was an adequate reflection of the larger school

demographic (Table 1). The majority of parental respondents were mothers $(81.7 \%)$ and either White (51.8\%) or Black (29.1\%). Like at Freedom, there was an underrepresentation of Hispanics $(9.9 \%)$ in the sample. The sample was socioeconomically diverse ranging from annual incomes of less than $\$ 20,000(28.9 \%)$ to annual incomes of over $\$ 50,000(25.2 \%)$. Educational attainment for parents at Sunrise was much higher than for parents at Freedom. Only $6 \%$ of parents reported having less than a high school education, 33\% received a high school diploma or GED, 38\% had some college, $14 \%$ had a Bachelor degree, and $9 \%$ had a graduate degree.

\section{Measures}

Parents at both schools received the same survey. All measures for the study were adopted or adapted from published scales relating to study constructs. Each measure used a 6-point Likert-type response scale, with higher scores indicating more frequent occurrences, or more agreement with standings on the construct. All underwent face and content validity evaluations by a panel of five persons with expert knowledge of the constructs being evaluated. 
Table 1. Summary of Demographic Statistics

\begin{tabular}{|c|c|c|c|c|c|}
\hline & Full sample & Freedom mic & ddle school & Sunrise mid & Idle school \\
\hline & $(\%)$ & School (\%) & Sample $(\%)$ & School (\%) & Sample $(\%)$ \\
\hline \multicolumn{6}{|l|}{ Student Ethnicity } \\
\hline Asian & 3.6 & 1.4 & 4.6 & 1.5 & 2.1 \\
\hline Black & 51.8 & 69.7 & 68.0 & 25.9 & 29.1 \\
\hline Hispanic & 6.5 & 9.5 & 4.1 & 13.7 & 9.9 \\
\hline White & 34.0 & 19.3 & 21.3 & 58.5 & 51.8 \\
\hline \multicolumn{6}{|c|}{ Students' Family SES variables } \\
\hline Free/reduced lunch & ------ & 90.5 & ------ & 50.1 & ------ \\
\hline Income $\leq 20 \mathrm{k}$ & 39.8 & & 47.6 & & 28.9 \\
\hline Income $20 \mathrm{k} \geq 30 \mathrm{k}$ & 21.9 & & 23.3 & & 20.0 \\
\hline Income $30 \mathrm{k} \geq 40 \mathrm{k}$ & 12.7 & & 13.2 & & 11.9 \\
\hline Income $40 \mathrm{k} \geq 50 \mathrm{k}$ & 10.5 & & 7.9 & & 14.1 \\
\hline Income $\geq 50 \mathrm{k}$ & 15.1 & & 7.9 & & 25.2 \\
\hline \multicolumn{6}{|c|}{17} \\
\hline
\end{tabular}




\section{Outcome variable.}

Parental role beliefs. Grounded in work summarized in Hoover-Dempsey et al., (2004), this 10-item measure assessed the extent to which a parent believes that he or she should be actively involved in the child's education. Responses for this measure were 1 (strongly disagree), 2 (disagree), 3 (disagree just a little), 4 (agree just a little), 5 (agree), 6 (strongly agree). Higher scores indicated beliefs supporting a more active parental role in the child's education; lower scores indicated beliefs supporting a less active or more passive role in the child's education. Participants were asked to respond to items by indicating the degree to which they believe they are responsible for behaviors such as "Volunteering at the child's school", "Communicating with my child's teacher regularly", and "Talk with my child about the school day". Alpha reliabilities for this scale were .79 at Freedom and .78 at Sunrise.

\section{Experiential predictor of role beliefs.}

Valence toward school. This six item measure assessed parents' attraction to or general disposition toward schools, based on prior experiences with schools. Respondents were asked to rate their experiences while a middle school student pertinent to selected perspectives on elements of schooling. Each of the elements was on a continuum: one

end was anchored by negative experiences, the other by positive experiences (e.g., My school: 1 = disliked, 6 = liked; My teachers: $1=$ ignored me, $6=$ cared about me). Higher scores indicated a stronger attraction or valence toward school; lower scores indicated lower attraction toward school. Alpha reliabilities for this scale were .89 at Freedom and .93 at Sunrise. 


\section{School predictors of role beliefs.}

\section{Parents' perceptions of general school invitations to involvement. Parents'}

perceptions of general school invitations to involvement was assessed using two subscales (empowerment-focused invitations and communication-focused invitations) of the Parents' Perceptions of General Invitations to Involvement from the School scale adapted from Griffith's Parent Satisfaction Survey. Responses for this measure were 1 (strongly disagree), 2 (disagree), 3 (disagree just a little), 4 (agree just a little), 5 (agree), or 6 (strongly agree). This scale had six items (three from each subscale) and included items such as "This school does a good job of letting me know about ways I can help out in school", "Parent activities are scheduled at this school so that I can attend", and "This school does a good job of letting me know about school rules and policies". Alpha reliabilities for this scale were .84 at Freedom and .80 at Sunrise.

Parents' perceptions of school climate. Parents' perception of school climate was assessed using the Sense of School Belonging scale developed by Goodenow (1993). Three items were removed because they did not fit the working definition of school climate used in this study. The remaining 15 items asked parents to indicate the extent to which they agreed with statements such as "Other people at the school take my opinion seriously", "The teachers at the school respect me", and "People at this school are friendly to me”. Responses for this measure were 1 (strongly disagree), 2 (disagree), 3 (disagree just a little), 4 (agree just a little), 5 (agree), 6 (strongly agree). Alpha reliabilities were .87 for Freedom and .90 for Sunrise. 


\section{Parents' perceptions of specific teacher invitations to involvement. Parents'}

perceptions of teachers' invitations to involvement was assessed with the six-item scale reported in Walker et al., (2005), which was developed during a three-year study of the parental involvement process (Hoover-Dempsey \& Sandler, 2005). To create the measure, researchers identified six common involvement behaviors that represent homebased activities (e.g., communicating with the child about the school day, helping the child with homework, supervising the child's homework) and school-based activities (e.g., helping out at the school, communicating with the teacher, attending special events at the school). Responses for this measure were 1 (never), 2 (one or two times), 3 (four or five times), 4 (once a week), 5 (a few times a week), or 6 (daily). Alpha reliabilities for this scale were .80 at Freedom and .76 at Sunrise.

Parents' perceptions of specific student invitations to involvement. This scale included student requests for parental involvement in six relatively common home-based and school-based involvement activities (e.g., "My child asked me to help explain something about his or her homework;" "My child asked me to help out at school"). Responses for this measure were 1 (never), 2 (one or two times), 3 (four or five times), 4 (once a week) 5 (a few times a week), or 6 (daily). Alpha reliabilities for the scale were .73 at Freedom and .74 at Sunrise. 


\section{CHAPTER III}

\section{RESULTS}

For all samples, zero-order correlations were calculated among the measures to examine the relationships using SPSS 19.0. Correlational analyses indicated instances of possible mediations, which were resolved using the Sobel (1982) test for mediation. To avoid the exclusion of possibly important relationships between variables because of a small mediation effect, significance levels for all mediations were set at $p<.01$. For this study, mediation occurred if a) the independent variable had a significant effect on the mediator, b) the mediator had a significant effect on the dependent variable, c) the independent variable had a significant effect on the dependent variable, and d) the effect of the independent variable on the dependent variable became non-significant when the mediator was included in the model. Once mediations were identified, path maps were drawn using AMOS 19.0 software. Simple regressions were conducted individually for each endogenous variable in the map and verified in AMOS.

Overall, the full sample of parents offered generally positive perceptions of study variables. On a scale of 1 (strongly disagree), 2 (disagree), 3 (disagree just a little), 4 (agree just a little), 5 (agree), 6 (strongly agree), most respondents indicated strong agreement with construct standings. As indicated in Table 2, most parents reported active role beliefs $(M=4.9, S D=.62)$ and positive valences towards schools $(M=4.97, S D=$ 1.08). In general, parents also reported positive perceptions of the schools' general 
invitations to involvement $(M=4.78, S D=.84)$ and school climates $(M=4.54, S D=$ .74). Additionally, parents reported receiving invitations to involvement from teachers four or five times during the school year $(M=2.56, S D=1.22)$ and invitations from children once a week $(M=3.45, S D=.95)$, using a scale of 1 (never), 2 (one or two times), 3 (four or five times), 4 (once a week), 5 (a few times a week), or 6 (daily). 
Table 2. Descriptive Statistics and Independent Sample $t$-tests

\begin{tabular}{lllll}
\hline & Full Sample & Freedom & Sunrise & \\
Scale & $\mathrm{M}(\mathrm{SD})$ & $\mathrm{M}(\mathrm{SD})$ & $\mathrm{M}(\mathrm{SD})$ & .75 \\
\hline Role activity beliefs & $4.90(.62)$ & $4.87(.65)$ & $4.92(.58)$ & $2.13^{*}$ \\
Valence toward school & $4.97(1.08)$ & $5.08(1.00)$ & $4.83(1.17)$ & 1.00 \\
General school invitations & $4.78(.84)$ & $4.74(.89)$ & $4.83(.79)$ & 1.06 \\
School climate & $4.54(.74)$ & $4.52(.77)$ & $4.62(.76)$ & $3.39 * * *$ \\
Teacher invitations & $2.56(1.23)$ & $2.77(1.29)$ & $2.31(1.11)$ & .61 \\
Student invitations & $3.45(.95)$ & $3.48(1.03)$ & $3.41(.87)$ & \\
\hline
\end{tabular}

+ Difference between Freedom and Sunrise is significant at the Bonferroni corrected .01 level

* Difference between Freedom and Sunrise is significant at the .05 level

*** Difference between Freedom and Sunrise is significant at the .001 level 
Correlations among study variables in the full sample were extensive (Table 3). Most notably, strong relationships existed between parents' role beliefs and their perceptions of general school invitations to involvement $(r=.52, p<.01)$, and role beliefs and parents' perceptions of school climate $(r=.50, p<.01)$. School climate was also highly correlated with parents' perceptions of general school invitations to involvement ( $r=.66, p<.01)$. Lastly, parents' perceptions of teachers' invitations to involvement was correlated with their perception of student invitations to involvement ( $r$ $=.53, p<.01)$.

Research Question One: Across the two schools, how were parents' valence toward school, perceptions of general school invitations, perceptions of school climate, perceptions of specific teacher invitations, and perceptions of specific student invitations related to their beliefs about their role in supporting their children's education?

Correlational analyses indicated significant relationships among all study variables. To better understand the strength of those relationships, mediations were conducted for all correlations. Five significant mediations emerged. The relationship between valence and parents' role beliefs was mediated by school climate $(z=4.49, p<$ .001 ), whereas the relationship between teacher invitations and parents' role beliefs was mediated by general school invitations $(z=5.53, p<.001)$. General school invitations also mediated the relationship between teacher invitations and school climate $(z=6.05, p$ $<.001)$, as well as student invitations and school climate $(z=4.85, p<.001)$. Lastly, the association between valence and student invitations was mediated by teacher invitations $(z=3.10, p<.01)$. 
Despite these mediations, the pattern of interactions among study variables remained complex (Figure 1). Thirty-five percent of the variance (Adj. $R^{2}=.35, f^{2}=.54$ ) in parents' role beliefs was accounted for by parents' perceptions of general school invitations $(\beta=.29, p<.001)$, school climate $(\beta=.27, p<.001)$, and children's invitations to involvement $(\beta=.21, p<.001)$. Parents' valence toward school and perceptions of teacher invitations to involvement had indirect effects on parents' role beliefs through other predictor variables. 
Table 3: Summary of Correlations for Full Sample

\begin{tabular}{|c|c|c|c|c|c|c|}
\hline$N=340)$ & a. & b. & c. & d. & e. & $\mathrm{f}$ \\
\hline a. Role beliefs & 1.00 & & & & & \\
\hline b. Valence & $.15 * *$ & 1.00 & & & & \\
\hline $\begin{array}{l}\text { c. General } \\
\text { School invitations }\end{array}$ & $.52 * *$ & $.17 * *$ & 1.00 & & & \\
\hline d. School climate & $.50 * *$ & $.26 * *$ & $.66^{* *}$ & 1.00 & & \\
\hline e. Teacher invitations & $.26^{* *}$ & $.17 * *$ & $.34 * *$ & $.24 * *$ & 1.00 & \\
\hline f. Student invitations & $.34 * *$ & $.17 * *$ & $.27 * *$ & $.21 * *$ & $.53 * *$ & 1.00 \\
\hline
\end{tabular}

** Correlation is significant at the .01 level (2-tailed) 
Valence Towards School
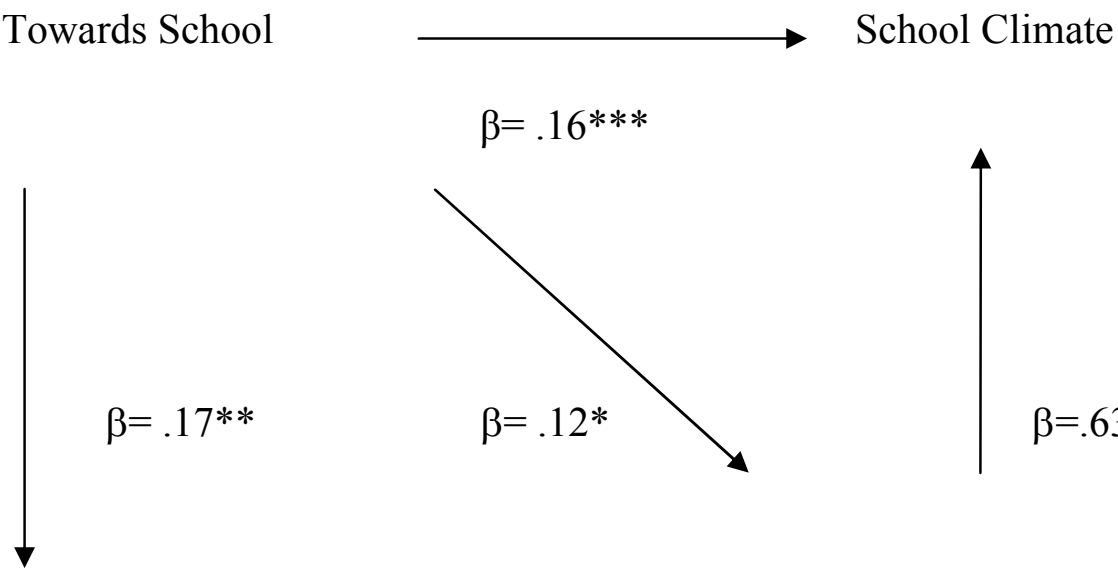

Teacher Invitations

$$
\beta=.28 * * *
$$

to Involvement

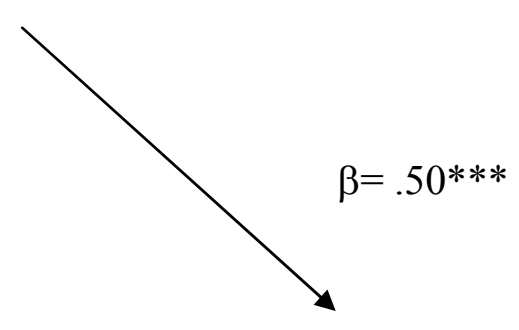

General School
Invitations to

Involvement

Student Invitations

to Involvement

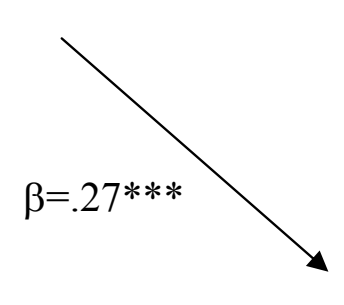

$$
\beta=.29 * * *
$$

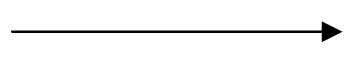

Role Beliefs
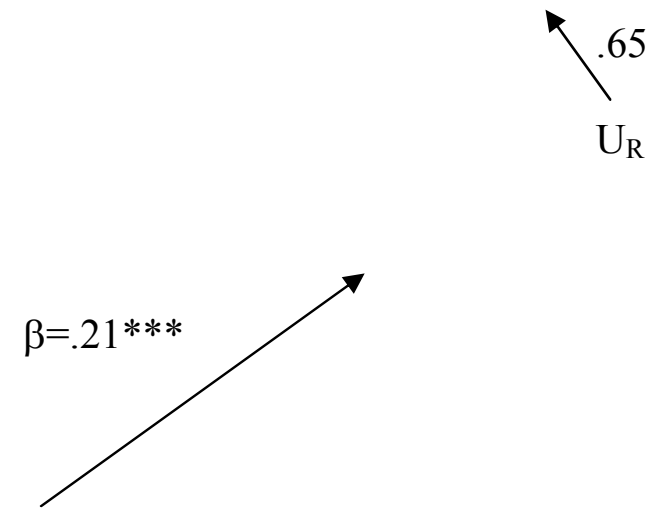

Figure 1: Path analysis map for full sample 
Research Question Two: Do parents' current experiences with schools influence their role beliefs differently than their prior experiences with schools?

Across the schools, parents' recent perceptions of school had a more powerful influence (average total effect of $r=.41$ ) on their role beliefs than did their valence toward school $(r=.15, p<.01)$ derived from their prior experiences. Most notably, parents' perceptions of general school invitations to involvement $(r=.52, p<.01)$, school climate $(r=.50, p<.01)$, and student invitations to involvement $(r=.34, p<.01)$ had the strongest total effects on parent's role beliefs. Parents' valence toward school did not have a direct path to parents' role, and instead, contributed indirectly through general school invitations $(r=.17, p<.01)$, teacher invitations $(r=.17, p<.01)$, and school climate $(r=.26, p<.01)$.

Research Question Three: Do the two schools differ significantly across study constructs and in their influence on parents' role beliefs?

In preparation for school-level comparisons, means and standard deviations for all measures were calculated for each school (Table 2). Independent sample t-tests were then conducted to compare means across the two samples. To avoid familywise errors, significance levels were adjusted using a Bonferroni correction (noted in Table 2).

The two schools were not statistically different across most study constructs. Parents at Freedom and Sunrise had active role beliefs $(M=4.87, S D=.65 ; M=4.92, S D$ $=.58, n s)$ and agreed that the schools did a good job of extending general school invitations $(M=4.74, S D=.89 ; M=4.83, S D=.79, n s)$ and creating a welcoming school climate $(M=4.52, S D=.77 ; M=4.62, S D=.76, n s)$. Additionally, parents at both 
schools perceived invitations to involvement from their children about once a week ( $M=$ 3.48, $S D=1.03 ; M=3.41, S D=.87, n s)$.

Parents across schools differed in two areas however. Parents at Freedom reported slightly more positive valences toward school $(M=5.80, S D=1.00)$ than did parents at Sunrise $(M=4.83, S D=1.17)(t=2.13, p<.05 ; d=.23)$, but this finding did not meet the Bonferroni corrected significance of .01. The largest difference between schools related to parents' perceptions of teacher invitations to involvement. Parents at Freedom reported having been invited by teachers four or five times throughout the year $(M=2.78, S D=1.29)$, whereas parents at Sunrise reported invitations occurring only once or twice during the year $(M=2.31, S D=1.11)(t=3.39, p<.001 ; d=.40)$.

\section{Freedom middle school.}

Relationships among study constructs revealed 13 significant correlations at Freedom (Table 4). From those relationships, three significant mediations emerged. Parents' perception of general school invitations mediated the relationship between teacher invitations and parents' role beliefs $(z=4.84, p<.001)$, student invitations and school climate $(z=4.39, p<.001)$, and teacher invitations and school climate $(z=5.01, p$ $<.001)$. 
The remaining paths (Figure 2) illustrate the direct and indirect effects of experiential and school predictors on parents' role beliefs. Forty-four percent of the variance (Adj. $R^{2}=.44, f^{2}=.79$ ) in parents' role beliefs was accounted for by parents' perception of general school invitations $(\beta=.43, p<.001)$, student invitations $(\beta=.24, p$ $<.001)$, and school climate $(\beta=.17, p<.05)$. Parents' valence toward school contributed indirectly through both general school invitations $(r=.24, p<.01)$ and school climate $(r$ $=.29, p<.01)$. Teacher invitations contributed indirectly through general school invitations $(r=.37, p<.01)$. 
Table 4: Summary of Correlations for Freedom Middle

\begin{tabular}{|c|c|c|c|c|c|c|}
\hline$N=198)$ & a. & b. & c. & d. & e. & f. \\
\hline a. Role beliefs & 1.00 & & & & & \\
\hline b. Valence & .12 & 1.00 & & & & \\
\hline $\begin{array}{l}\text { c. General } \\
\text { School invitations }\end{array}$ & $.62 * *$ & $.24 * *$ & 1.00 & & & \\
\hline d. School climate & $.50 * *$ & $.29 * *$ & $.66^{* *}$ & 1.00 & & \\
\hline e. Teacher invitations & $.31 * *$ & $.18^{*}$ & $.37 * *$ & $.27 * *$ & 1.00 & \\
\hline f. Student invitations & $.42 * *$ & .12 & $.32 * *$ & $.23 * *$ & $.57 * *$ & 1.00 \\
\hline
\end{tabular}

* Correlation is significant at the 0.05 level (2-tailed)

** Correlation is significant at the 0.01 level (2-tailed) 
Valence Towards School

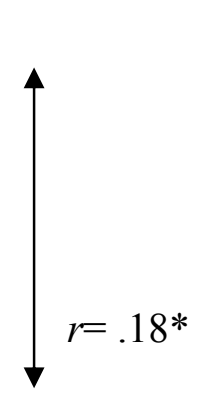

Teacher Invitations

to Involvement
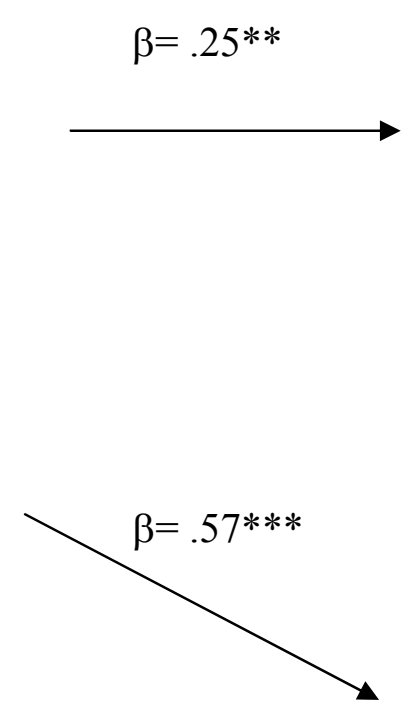

School Climate

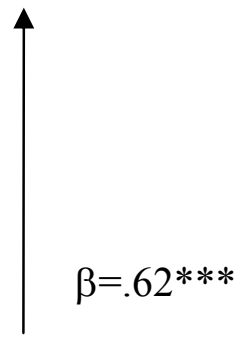

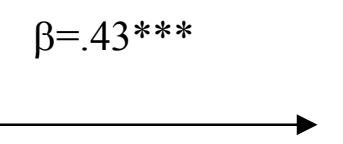

Involvement

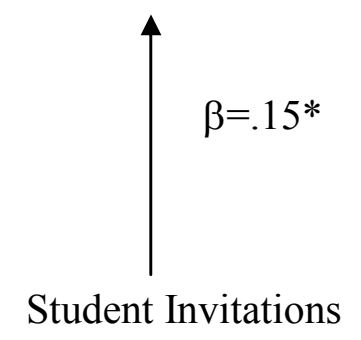

to Involvement

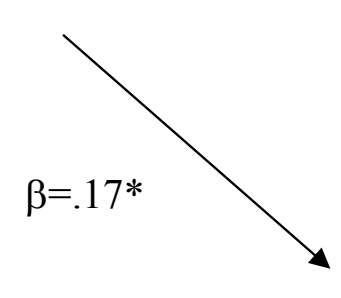

Role Beliefs
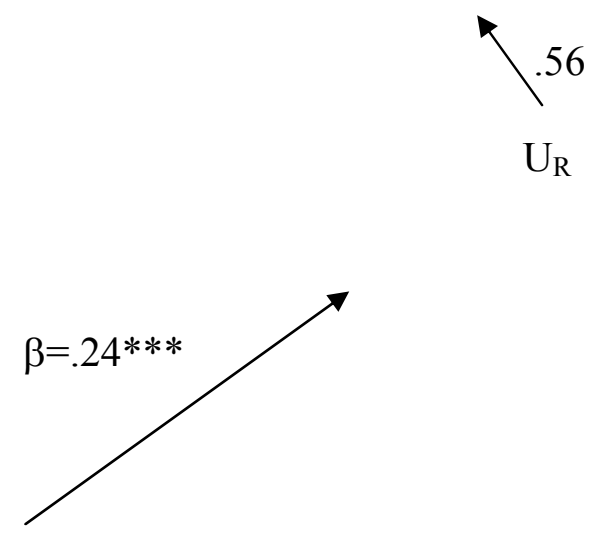

Figure 2: Path analysis map for Freedom middle school 


\section{Sunrise middle school.}

Relationships among study constructs were equally complex at Sunrise (Table 5). Five significant mediations emerged from the 13 correlations. Parents' perception of school climate mediated the relationship between valence and role beliefs $(z=2.73, p<$ $.01)$ and general school invitations and role beliefs $(z=4.26, p<.001)$. The association between teacher invitations and role beliefs was mediated by general school invitations $(z$ $=2.73 p<.01$ ), which also mediated the relationship between teacher invitations and school climate $(z=3.76, p<.001)$. The relationship between student invitations and general school invitations was mediated by teacher invitations to involvement $(z=3.01 p$ $<.01)$.

These mediations left a fairly simple illustration of the direct and indirect effects of study variables on parents' role beliefs (Figure 3). Parents' perception of school climate $(\beta=.46, p<.001)$ and student invitations $(\beta=.13, n s)$ had direct paths to parents' role beliefs which accounted for $24 \%$ of its variance $\left(\right.$ Adj. $\left.R^{2}=.24, f^{2}=.32\right)$. All other variables were indirectly related to role beliefs through other study variables. Valence had a direct effect on school climate $(r=.25, p<.01)$, while teacher invitations had a direct effect on general school invitations $(r=.33, p<.01)$. General school invitations had a direct effect on school climate $(r=.66, p<.01)$. 
Table 5: Summary of Correlations for Sunrise Middle

\begin{tabular}{|c|c|c|c|c|c|c|}
\hline$N=142)$ & a. & b. & c. & d. & e. & f. \\
\hline a. Role beliefs & 1.00 & & & & & \\
\hline b. Valence & $.21 *$ & 1.00 & & & & \\
\hline $\begin{array}{l}\text { c. General } \\
\text { School invitations }\end{array}$ & $.34 * *$ & .10 & 1.00 & & & \\
\hline d. School climate & $.48 * *$ & $.25 * *$ & $.66^{* *}$ & 1.00 & & \\
\hline e. Teacher invitations & $.19 *$ & .12 & $.33 * *$ & $.24 * *$ & 1.00 & \\
\hline f. Student invitations & $.21 *$ & $.23 * *$ & $.18^{*}$ & $.18^{*}$ & $.47 * *$ & 1.00 \\
\hline
\end{tabular}

* Correlation is significant at the 0.05 level (2-tailed)

** Correlation is significant at the 0.01 level (2-tailed) 


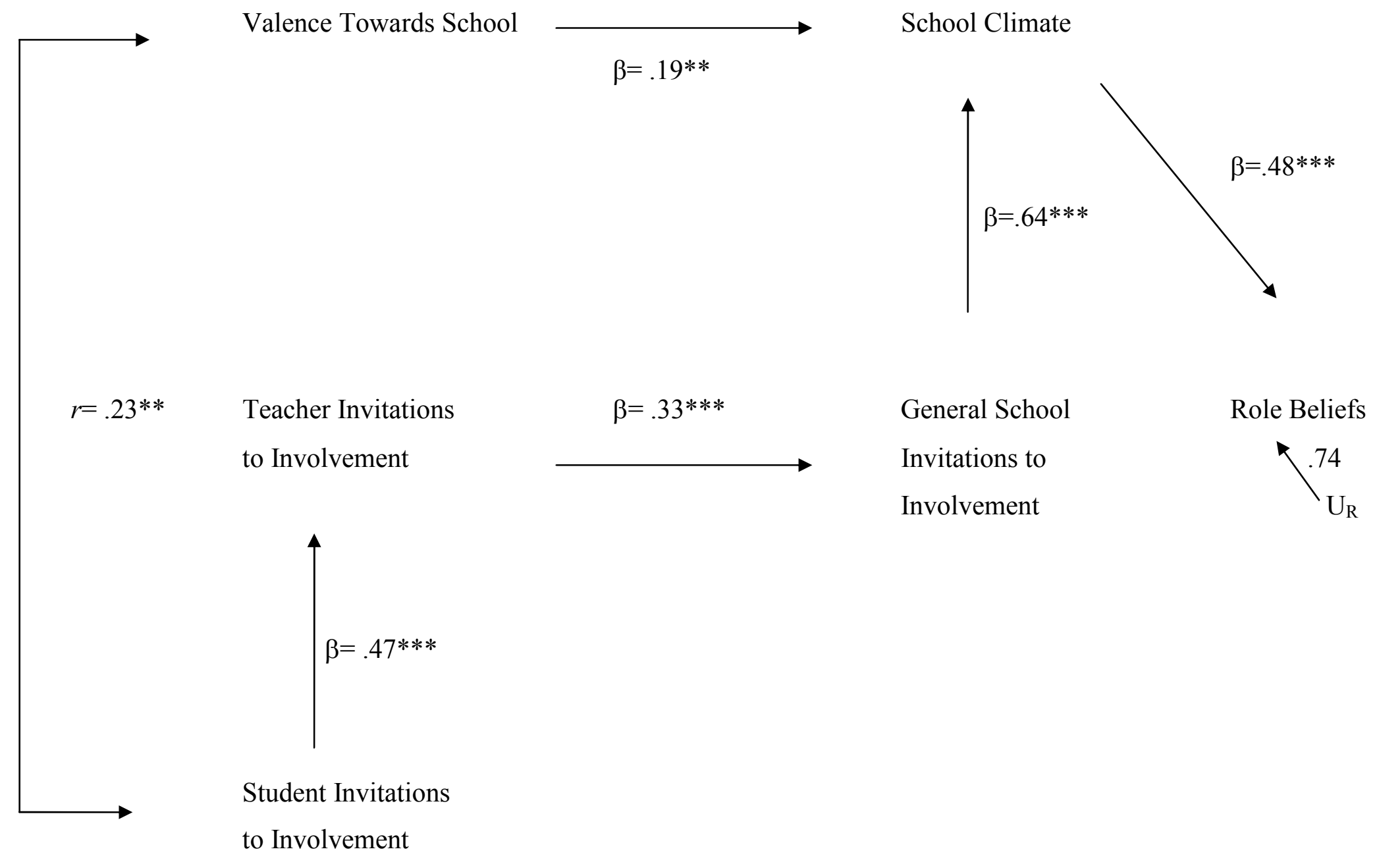

Figure 3: Path analysis map for Sunrise middle school 


\section{CHAPTER IV}

\section{DISCUSSION}

Findings of this study demonstrate that what we know to be motivators of parental involvement behaviors, are also motivators of parental involvement beliefs. Parents' perceptions of general school invitations to involvement, school climate, and student invitations to involvement predicted parents' role beliefs related to involvement in their child's education. Parents' current experiences with schools and teachers were more powerful than prior school experiences in predicting parents' role beliefs. Study findings also suggest that differences in administrative approaches to parental involvement do not influence if parents have active role beliefs; rather, different administrative approaches to parental involvement may influence how parents come to have active role beliefs.

Across the two schools, parents' perceptions of general school invitations, school climate, and student invitations to involvement were the most influential variables predicting parents' role beliefs. The finding of general school invitations to involvement as a predictor is somewhat surprising given prior findings that general school invitations are not influential motivators of parents' involvement behaviors (Green et al., 2007). While parents may not perceive general school communications as explicit invitations to be involved, they may in fact perceive such communications as indicative of school expectations for involvement. For example, general school invitations at both schools contained information stating they want parent involvement, describing ways in which parents can be involved (e.g. volunteering, school governance, parent workshops), and 
listing all methods of communication available to parents (e.g. student agendas, suggestion box, phone numbers for parent liaison). The present findings suggest that parents indeed used such information as indicators of what their role should be in their child's schooling.

Parents' perception of school climate was the second most influential predictor of parents' role beliefs. Most studies (Comer, 1995; Griffith, 1998; Lopez, Sanchez, \& Hamilton, 2000; Scribner, Young, \& Pedroza, 1999) investigating school climate use measures with three or four items that better reflect general school invitations (e.g. 'The school does a good job of letting me know about school rules and policies'; 'The school lets me know about meetings and special school events') than parents' perception of the school environment. The power of school climate in the present study may reflect the comprehensive measure used to assess how welcoming the school is of parents' participation (e.g. 'I feel like a real part of my child's school'; 'Other people at my child's school take my opinion seriously'; 'People at my child's school are friendly to me'). Parents in this study appeared to have perceived a respectful and friendly environment that may have helped them to interpret general school invitations as indicative of not only school expectations, but also, the school's desires for parental involvement.

The final direct predictor of role beliefs was parents' perception of student invitations to involvement. This finding is consistent with previous work demonstrating student invitations to be the most powerful predictor of parents' involvement behaviors (Anderson \& Minke, 2007; Deslandes \& Bertrand, 2005; Green et al., 2007; HooverDempsey et al., 2005; Sheldon, 2002). This variable may also help parents develop ideas 
about their role because student invitations are essentially a direct request from a powerful social source in the educational context. Similar to general school invitations, specific invitations from their children may help them define their responsibilities in their role.

Also interesting within the pattern of interactions among variables, was the contribution of teachers' invitations to parents' role beliefs. Although previous work cites teacher invitations as strong motivators of parental involvement (Balli et al., 1998; Dauber \& Epstein, 1993; Epstein, 1986; Epstein \& Van Voorhis, 2001), the present study did not find teacher invitations to have a direct effect on parents' role beliefs. The indirect effect is probably due to the low occurrence of teacher invitations. Teacher invitations are probably low because teachers at both schools reported teaching between 225-500 students per day. With so many students, it is not possible for teachers to send all parents specific invitations pertinent to individual students. Consequently, it is common practice in many schools for teacher 'teams' (e.g. $5^{\text {th }}$ grade teachers, algebra teachers) to send parents information related to a specific grade or subject. In such instances, parents may therefore classify any invitation to involvement as a 'general school' invitation instead of a specific teacher invitation.

The weakest predictor of role beliefs was parents' valence toward school. This variable represented parents' overall attitude toward school based on their prior experiences. It was included in the study to compare the influence of past and present experiences, on parents' ideas about their responsibilities in their children's education. Interestingly, though valence had the least effect on role beliefs, it had a direct or indirect effect on each of the other study variables. These relationships suggest that parents may 
use their childhood schooling experiences to 'set the stage' for their interactions in their children's schools. In other words, it may be that parents view current school parent involvement initiatives through the lens of previous experiences.

\section{School Differences}

In addition to examining the interrelationships among parents' perceptions of contextual invitations to involvement, this study also sought to examine the possibility that different administrative approaches to parental involvement might also influence parents' role beliefs. The two schools in this study differed in the structure and execution of parental involvement initiatives. At Freedom, a parent involvement coordinator was the primary person responsible for inviting parent participation, whereas at Sunrise, with no involvement coordinator, invitations to involvement were largely the responsibility of classroom teachers, overseen by the principal. In general, parents across the schools reported very similar perceptions of general school invitations to involvement, student invitations to involvement, and school climate, as well as similarly active role beliefs. The only significant difference between schools was in parents' perception of teacher invitations to involvement.

Parents at Freedom reported higher perceptions of teacher invitations than parents at Sunrise. Invitations from teachers at Freedom may have been more frequent because there was a parent involvement coordinator who encouraged teachers to invite parents. In general, the involvement coordinator at Freedom developed and implemented parent involvement programs, and teachers sent home the invitations the coordinator created. 
There were also differences in the patterns of findings for predictors of parents' role beliefs between the schools. At Freedom, general school invitations emerged as the most powerful predictor of parents' role beliefs. School invitations may have been particularly powerful at Freedom because the parent involvement coordinator extended diverse and plentiful school-wide invitations (e.g. to parent focus groups, workshops, family trivia night) throughout the school year. At Sunrise, these tasks often fell to office staff and teachers as a small part of their job requirements.

The weakness of general school invitations to involvement at Sunrise is therefore unsurprising. Without an involvement coordinator, the general school invitations may have been too infrequent or too impersonal to significantly affect parents' understanding of their role. Conversely, parents' perception of the school climate at Sunrise was particularly powerful in influencing parents' role beliefs. Because parents at both schools perceived generally positive school climates, the power of school climate at Sunrise may reflect the quantity of experiences with the school, not the quality.

The absence of a parent involvement coordinator at Sunrise meant parents lacked a 'point person' to contact with questions or concerns. Parents at Sunrise likely communicated with multiple teachers and office staff throughout the school year, thereby giving them more experiences with school personnel. With more exposure to more people, parents at Sunrise probably had more comprehensive assessments of the school's climate than did parents at Freedom, who likely used the involvement coordinator as their first point of contact with the school. The quantity of parents' interactions with school personnel compared to the smaller quantity of invitations to involvement received from 
the school, made school climate the strongest source of influence on parents' role beliefs at Sunrise.

\section{Sample differences.}

It is quite possible that demographic differences among school samples contributed to the different patterns of interaction among variables. Although both schools were Title I schools, parents' ethnicity, annual income, and level of education differed across the samples. These differences are important because research and theory suggest that demographic characteristics greatly influence the amount of social capital parents posses and bring to their understanding of new social roles (Burchinal, Follmer, \& Bryant, 1996; Horvat, Weininger, \& Lareau, 2003; VanVelsor \& Orozco, 2007).

Bordieu (1985) stated that social capital is derived from the benefits accruing to individuals by virtue of participation in groups. He proposed that social capital is decomposable into two elements: 1) the social relationship itself that allows individuals to claim access to resources possessed by their associates, and 2) the amount and quality of those resources. Thus, in an educational context, social capital includes the material (e.g. money) and immaterial (e.g. relationships) educationally relevant resources that individuals and families are able to access through their social ties (Portes, 1998).

The sample from Freedom was comprised primarily of low-income parents with relatively low levels of education. Characteristics such as these often mean that parents do not have extensive social capital to invest in their children's schooling. More specifically for example, these parents may not have personal experiences or social networks that contributed to their understanding of parental involvement (Sheldon, 2002). Fewer than half of the sample from Freedom had educational experiences beyond high 
school, suggesting that these parents may not have known the longer term benefits of having a parent actively involved in schooling. In such circumstances, it would seem logical that these parents might rely more heavily on the school to inform them of parental involvement expectations (through general school invitations to involvement, student invitations to involvement, and the overall school climate) than might parents with higher levels of education.

These avenues of communication may have been particularly powerful at Freedom because they came from sources parents were likely to trust. Sixty-eight percent of respondents at Freedom were Black. All of the office staff, the parent involvement coordinator, and all but two teachers at the school were also Black. Research indicates that parents are more likely to establish bonds with people who are of similar ethnicity and social class than if they are not (Goddard, Tschannen-Moran, \& Hoy, 2001; Lareau \& Horvat, 1999). These similarities may have increased the sense of community at Freedom, which in turn, may have created a strong social network for parents within the school, thus contributing to parents' positive perception of the school's climate.

Social capital theory suggests however, that parents' social networks at Sunrise existed beyond the school. Because of their higher education and income levels, parents at Sunrise likely had social ties with well educated and economically stable people that extended beyond the school. Perhaps more than Freedom parents, Sunrise parents may have had what Coleman (1988) called community social capital—the benefits of being embedded in social relationships with other families and community institutions who share attitudes, beliefs, and behaviors that bind the network. It may be that parents at Sunrise — more so than parents at Freedom—-had friends and family who endorsed and 
modeled parents' participation in children's learning. It is therefore possible that parents at Sunrise may have experienced and understood more about the value of parental involvement to children's learning than Freedom parents. Consequently, invitations to involvement from the school, teachers, or students may not have been essential to their development of their role construction for involvement. The importance of school climate in the construction of their role suggests that it is however, necessary for the school to convey they want parental involvement.

\section{Limitations}

While offering interesting suggestions about school-based contributors to parents' beliefs about their roles in their children's education, the study had its limitations. First, it is possible that parents who choose to complete surveys about parent involvement are somewhat more involved in their child's schooling than parents who choose not to participate, thereby introducing the probability of bias in the sample. Second, although similar in many respects (e.g. both were high achieving Title I schools), the schools differed in potentially important ways (e.g. school demographics). Freedom middle served a low-income racial minority population, whereas parents at Sunrise middle were socioeconomically and ethnically diverse. These differences limit the extent to which findings can be generalized across the samples, and more broadly, to Title I schools.

In addition, though consistent with research in the field, response rates for both schools were not high, and thus underscore limits on the extent to which findings may be generalized. This is partially due to methodological constraints in which the school district did not allow surveys to be sent directly to parents. Response rates were also 
depressed by a natural disaster that destroyed some data at one school, and diverted many parents' attention across the two schools to personal concerns regarding housing, employment, and financial recovery.

Lastly, the data in this study were based on self-reports. Parents' reported perceptions of all school, teacher, and student invitations were not corroborated by any other source. Examining how parents' perceptions of study variables compared to teachers' and students' reports related to the same variables would have provided a fuller view of school functioning in these domains, but was beyond the scope of this study.

\section{Implications for Research}

This study was a modest beginning to understanding how schools influence parents' construction of their role in their children's education. The findings offer suggestions for increasing the breadth and depth of knowledge surrounding parents' role beliefs in middle schools. First, like any novel study, this study should be replicated in other Title I schools, as well as schools similarly situated in urban settings, but serving different demographics of students and families (e.g. ethnically diverse, wealthier, higher achieving). These studies would allow a broader understanding of how Title I schools approach parental involvement, and how those approaches compare to parent involvement initiatives in schools without Title I funding.

Second, not all variables in this study were significantly related to parents' role beliefs. Those most powerfully predictive of role beliefs were parents' perceptions of general school invitations, school climate, and student invitations to involvement. Future research should expand upon the present findings by deepening the extent to which each 
of the aforementioned variables is examined. In particular, due to the finding that general school invitations were most influential to parents' role beliefs, it would be prudent to assess the quantity and quality of invitations sent to parents from the school. Issues related to tone, clarity, and type of information relayed seem especially relevant to parents' comprehending the schools' expectations for parental involvement.

Additionally, it seems equally important to more fully assess parents' prior experiences with schools. Through interviews, parents can describe their relationships with teachers during their schooling, their experiences observing their own parents' involvement behaviors, and discuss how those experiences contributed to their current ideas about parental involvement. It may be that certain aspects of parents' experiences not measured in this study affect their construction of their role in their children's schooling.

Third, gathering data from teachers would facilitate comparisons between teachers' and parents' perceptions of school parental involvement initiatives. It would also allow comparisons of teachers' and parents' beliefs about their respective roles and responsibilities in establishing family-school partnerships. Such information could identify 'road blocks' in the processes of building family-school relationships, and elucidate the reasons why low-income parents are perceived by teachers as less involved in students' learning (Epstein \& Dauber, 1991; Klimes-Dougan, 1992; Moles, 1993).

Lastly, though a minor focus of this study, differences in administrative approaches to parent involvement between the two schools may have been influential in how school variables influenced parents' role beliefs. It would be informative to more fully examine how schools, prioritize involvement, allocate responsibility for 
involvement, and assess the effectiveness of their parent involvement initiatives. One or more of these organizational characteristics may be particularly relevant to the development of parents' role beliefs.

\section{Implications for Practice}

The findings of the study have implications for what schools may do to ensure parents are actively engaged in students' education. The results suggest that general school invitations to involvement are especially important avenues of communication with parents. Instead of merely meeting district requirements for notifying parents of school rules and policies, schools should establish a continual line of communication with parents that relays important information pertinent to students' learning (Chrispeels \& Rivero, 2001; Simon, 2004). Most notably, parents would benefit from school invitations that outline academic goals and timelines, explicitly describe school expectations for involvement, and offer diverse opportunities for involvement with clear explanations of how parents' participation increases student learning.

This study also has implications for how teachers should interact with parents. Parents' role beliefs at both schools were predicted in part by parents' positive perceptions of the schools' climates related to parent involvement. This suggests that teachers should communicate respectfully and courteously with parents, and in a way that relays the school's appreciation for parents' involvement. A positive school climate underscores the need for principals to share with teachers the importance of parent involvement to student achievement, and to hold teachers accountable for helping create a welcoming school climate (Christenson, 2004; Griffith, 2001). 
Finally, students' invitations to involvement were a significant predictor of parents' role beliefs. This finding affirms previous work (e.g. Anderson \& Minke 2007; Deslandes \& Bertrand, 2005; Sheldon, 2002) noting the importance of children's requests for parents' engagement in school related activities to parents' decisions about involvement. These findings suggest that teachers should consider creating assignments that prompt students to involve parents in meaningful ways that encourage parents to be active participants in students' learning.

\section{Conclusion}

This study reiterates the need for continued investigation into parent involvement in low-income, urban schools. Though important, it is not enough to know what parents do to be involved; we must expand our knowledge to include understandings of how parents come to be involved. Given the persistent achievement gap between low-income and upper-income students, it is critical that researchers and educators devise new methods of accessing and engaging parents whose life circumstances do not easily facilitate involvement in their children's schooling. This study suggests three paths through which schools can influence low-income parents' beliefs about their responsibilities to their children, and in their children's education. 


\section{REFERENCES}

Adams, K.S., \& Christenson, S.L. (2000). Trust and the family-school relationship examination of parent-teacher differences in elementary and secondary grades. Journal of School Psychology, 38(5), 477-497.

Anderson, K.J. \& Minke, K.M. (2007). Parent involvement in education: toward an understanding of parents' decision making. The Journal of Educational Research, $100,311-324$.

Auerbach, S. (2007). From moral supporters to struggling advocates: Reconceptualizing parent roles in education through the experience of workinng-class families of color. Urban Education, 42(3), 250-283.

Balli, S.J., Demo, D.H., \& Wedman, J.F. (1998). Family involvement with children's homework: An intervention in the middle grades, Family Relations, 47(2), 149157.

Bandura, A. (1997). Self-efficacy: The exercise of control. New York: W.H. Freeman and Company.

Biddle, B.J. (1986). Recent developments in role theory. Annual Review of Sociology, $12,67-92$.

Bourdieu, P. (1985). The forms of capital. In J.G. Richardson (Ed.). Handbook of theory and research for the sociology of education. New York: Greenwood.

Buckley, J., Schneider, M., \& Shang, Y. (2005). Fix it and they might stay: School facility quality and teacher retention in Washington, D.C. Teachers College Record, 107(5), 1107-1123.

Burchinal, M., Follmer, A., \& Bryant, D. (1996). The relations of maternal social support and family structure with maternal responsive and child outcomes among AfricanAmerican families. Developmental Psychology, 32, 1073-1083.

Chrispeels, J., \& Rivero, E. (2001). Engaging Latino families for student success: How parent education can reshape parents' sense of place in the education of their children. Peabody Journal of Education, 76, 119-169.

Christenson, S.L. (2004). The family-school partnership: An opportunity to promote the learning competence of all students. School Psychology Review, 33(1), 83-104.

Coleman, J. (1987). Families and schools. Educational Researcher, 16, 32-38. 
Coleman, J. (1988). Social capital in the creation of human capital. American Journal of Sociology Supplement 94: S95-S120.

Comer, J. (1995). School power: Implications of an intervention project. New York: The Free Press.

Comer, J., \& Schraft, S. (1995). Working with Black parents. In R. Abidin, Handbook of Parent Education. Illinois: Charles C. Thomas Publishers.

Corcoran, T.B. (1988). Working in Urban Schools. Washington, DC: Institute for Educational Leadership.

Crane, J. (1996). Effects of home environment, SES, and maternal test scores on mathematics achievement. Journal of Education Research, 89, 305-314.

Dauber, S.L. \& Epstein, J.L. (1993). Parents' attitudes and practices of involvement in inner-city elementary and middle schools. In N.F. Chavkin (Ed.), Families and schools in a pluralistic society (pp. 53-71). Albany, NY: State University of New York Press.

Desimone, L. (1999). Linking parent involvement with student achievement: Do race and income matter? Journal of Education Research, 93, 11-30.

Deslandes, R. \& Bertrand, R. (2005). Motivation of parent involvement in secondarylevel schooling. Journal of Educational Research, 98, 164-75.

Epstein, J.L. (1986). Parents' reactions to teacher practices of parent involvement. Elementary School Journal, 86, 277-294.

Epstein, J. L. (1988). How do we improve programs for parent involvement? Educational Horizons, 66, 58-59.

Epstein, J.L. (1990). School and family connections: Theory, research, and implications for integrating sociologies of education and family. In D.G. Unger \& M.B. Sussman, Families in community settings: Interdisciplinary perspectives (pp. 99126). New York: Haworth.

Epstein, J.L. \& Dauber, S.L. (1991). School programs and teacher practices of parent involvement in inner-city elementary and middle schools. Elementary School Journal, 91, 291-305.

Epstein, J.L., \& Van Voorhis, F.L. (2001). More than minutes: Teachers' roles in designing homework. Educational Psychologist, 36, 181-193. 
Fan, X., \& Chen, M. (2001). Parental Involvement and Students' Academic Achievement: A Meta-Analysis. Educational Psychology Review, 13, 1-22.

Fine, M. (1993). Parent involvement: Reflections on parents, power, and urban public schools. Teachers College Record, 94, 682-710.

Garcia Coll, C., Akiba, D., Palacios, N., Bailey, B., Silver, R., DiMartino, L., \& Chin, C. (2002). Parental involvement in children's education: Lessons from three immigrant groups. Parenting: Science and Practice, 2(3), 303-324.

Goddard, R.D., Tschannen-Moran, M., \& Hoy, W.K. (2001). A multilevel examination of the distribution and effects of teacher trust in students and parents in urban elementary schools. The Elementary School Journal, 102(1), 3-17.

Goodenow, C. (1993). The psychological sense of school membership among adolescents: Scale development and educational correlates. Psychology in the Schools, 30, 80-90.

Gordon, 1. J., \& Breivogel, W. F. (1976). Building effective home-school relationships. Boston: Allyn and Bacon.

Green, S.R. (2001). Closing the achievement gap: Lessons learned and challenges ahead. Teaching and Change, 8, 215-224.

Green, L.R., Blasik, K., Hartshorn, K., \& Shatten-Jones, E. (2000). Closing the achievement gap in science: A program to encourage minority and female students to participate and succeed. ERS Spectrum, 18, 3-13.

Green, C. L. \& Hoover-Dempsey, K. V. (2007). Why do parents home-school? A systematic examination of parental involvement. Education and Urban Society, $39,264-285$.

Green, C. L., Walker, J. M. T., Hoover-Dempsey, K. V., \& Sandler, H. M. (2007). Parents' motivations for involvement in children's education: An empirical test of a theoretical model of parental involvement. Journal of Educational Psychology, 99, 532-544.

Griffith, J. (1998). The relation of school structure and social environment to parent involvement in elementary schools. The Elementary School Journal, 99(1), 53-80.

Griffith, J. (2001). Principal leadership of parent involvement. Journal of Educational Administration, 39, 162-186.

Grolnick, W.S., Benjet, C., Kurowski, C.O., \& Apostolaris, N.H. (1997). Predictors of parent involvement in children's schooling. Journal of Educational Psychology, $89,538-548$. 
Grolnick, W.S., \& Slowiaczek, M.L. (1994). Parents' involvement in children's schooling: A multidimensional conceptualization and motivational model. Child Development, 65, 237-252.

Hart, A.W. (1992). The social and organizational influence of principals evaluating in context. Peabody Journal of Education, 68(1), 37-57.

Henderson, A.T., \& Mapp, K.L. (2002). A new wave of evidence: The impact of school, family, and community connections on student achievement. Austin, TX: National Center for Family and Community Connections with Schools, Southwest Educational Development Laboratory.

Hoover-Dempsey, K.V., Bassler, O.C., \& Brissie, J.S. (1992). Explorations in parentschool relations. Journal of Educational Research, 85, 287-294.

Hoover-Dempsey, K.V., Bassler, O.C., \& Burrow, R. (1995). Parents' reported involvement in students' homework: Strategies and practices. Elementary School Journal, 95, 435-450.

Hoover-Dempsey, K.V., Ice, C.L., \& Whitaker, M.C. (2009). We're Way Past Reading Together: Why and how parent involvement in adolescence makes sense. In N. E. Hill \& R.K. Chao (Eds.), Families and Schools and the Adolescent (pp. 19-36). New York: Teachers College Press.

Hoover-Dempsey, K.V., \& Jones, K.P. (1997, March). Parental role construction and parental involvement in children's education. Paper presented at the annual meeting of the American Educational Research Association, Chicago.

Hoover-Dempsey, K.V. \& Sandler, H.M. (1995). Parental involvement in children's education: Why does it make a difference? Teachers College Record, 97, 310331.

Hoover-Dempsey, K.V., \& Sandler, H. (1997). Why do parents become involved in their children's education? Review of Educational Research, 67, 3-42.

Hoover-Dempsey, K.V., Whitaker, M.C., \& Ice, C.L. (2010). Motivation and commitment to family-school partnerships. In Christenson, S.L., \& Reschly, A.L. (Eds.), Handbook on school-family partnerships for promoting student competence (pp. 30-60). New York, NY: Routledge/Taylor and Francis Group.

Hoover-Dempsey, K.V., Wilkins, A.S., Sandler, H.M., Jones O’Connor, K.P. (2004, April). Parental role construction and parental involvement: Interactions among theoretical, measurement, and pragmatic issues in instrument development. Paper presented at the annual meeting of the American Educational Research Association, San Diego. 
Horvat, E.M., Weininger, E., \& Lareau, A. (2003). From social ties to social capital: Class differences in the relation between school and parent networks. American Educational Research Journal 40 (2), 319-351.

Ibañez, G. E., Kuperminc, G. P., Jurkovic, G., \& Perilla, J. (2004). Cultural variables and adaptations linked to achievement motivation among Latino adolescents. Journal of Youth and Adolescence, 33, 559-568.

Ingram, M., Wolfe, R.B., \& Lieberman, J.M. (2007). The role of parents in high achieving schools serving low-income, at-risk populations. Education and Urban Society, 39(4), 479-497.

Jeynes, W.H. (2005). The effects of parental involvement on the academic achievement of African American youth. The Journal of Negro Education, 74, 260-275.

Jeynes, W.H. (2007). The relationship between parental involvement and urban secondary school student academic achievement: A meta-analysis. Urban Education, 42, 82-110.

Ji, C.S., \& Koblinksy, S.A. (2009). Parent involvement in children's education: An exploratory study of urban, Chinese immigrant families. Urban Education, 44(6), 687-709.

Jones, L., White, C.S., Aeby, V., \& Benson, B. (1997). Attitudes of early childhood teachers toward family and community involvement. Early Education and Development, 8(2), 153-163.

Kaplan, D.S., Liu, X., \& Kaplan, H.B. (2001). Influence of parent's self-feelings and expectations on children's academic performance. Journal of Education Research, 94, 360-370.

Klimes-Dougan, B. (1992). Two studies of low-income parents' involvement in schooling. Urban Review, 4(3), 185-202.

Lankford, H., Loeb, S., \& Wyckoff, J. (2002). Teacher sorting and the plight of urban schools: A descriptive analysis. Educational Evaluation and Policy Analysis, 24(1), 37-62.

Lareau, A. (1987). Social class differences in family-school relationships: The Importance of cultural capital. Sociology of Education, 60, 73-85.

Lareau, A., \& Horvat, E.M. (1999). Moments of social inclusion and exclusion: Race, class, and cultural capital in family-school relationships. Sociology of Education, 72, (1), 37-53. 
Lawson, M.A. (2003). School-family relations in context: Parent and teacher perceptions of parent involvement. Urban Education, 38(1), 77-133.

Lee, P.W. (1999). In their own voices: An ethnographic study of low-achieving students within the context of school reform. Urban Education, 34(2), 214-244.

Lee, J.S. \& Bowen, M.K. (2006). Parent involvement, cultural capital, and the achievement gap among elementary school children. American Educational Research Journal, 43, 193-218.

Lopez, L.C., Sanchez, V.V., \& Hamilton, M. (2000). Immigrant and native-born Mexican-American parents' involvement in a public school: A preliminary study. Psychological Reports, 86, 521-525.

Maccoby, E.E. (1980). Sex roles. In Social development: Psychological growth and the parent-child relationship (pp. 232-233). New York: Harcourt Brace Jovanovich.

McKay, M.M., Atkins, M.S., Hawkins, T., Brown, C., \& Lynn, C.J. (2003). Inner-City African American parental involvement in children's schooling: Racial socialization and social support from the community. American Journal of Community Psychology, 32(1/2), 107-114.

McWayne, C., Campos, R., \& Owsianik, M. (2008). A multidimensional, multilevel examination of Mother and father involvement among culturally diverse Head Start families. Journal of School Psychology, 46(5), 551-573.

Moles, O.C. (1993). Collaboration between schools and disadvantaged parents: obstacles and openings. In N.F. Chavkin (Ed.), Families and schools in a pluralistic society (pp.21-49). Albany: State University of New York Press.

Moll, L., Amanti, C., Neff, D. \& Gonzalez, N. (1992). Funds of knowledge for teaching: Using a qualitative approach to connect homes and classrooms. Theory Into Practice, 31, 132-141.

Moos, R.H. (1979). Evaluating educational environments. San Francisco: Jossey-Bass.

Murry, V.M., Kotchick, B.A., Wallace, S., Ketchen, B., Eddings, K., Heller, L., \& Collier, I. (2004). Race, culture and ethnicity: Implications for a community intervention. Journal of Child and Family Studies, 13(1), 81-99.

No Child Left Behind Act, 107 U.S.C., 1118 (2002).

O'Connor, S. (2001). Voices of parents and teachers in a poor white urban school. Journal of Education for Students Placed at Risk, 6(3), 175-198. 
Pang, I., \& Watkins, D. (2000). Towards a psychological model of teacher-parent communication in Hong Kong primary schools. Educational Studies, 26(2), 141163.

Pomerantz, E.M., Grolnick, W.S., \& Price, C.E. (2005). The role of parents in how children approach achievement: A dynamic process perspective. In A.J. Elliott \& C.S. Dweck (Eds.), Handbook of motivation and competence (pp. 259-278). New York: Oxford.

Portes, A. (1998). Social capital: its origins and applications in modern sociology. Annual Review of Sociology, 24, 1-24.

Reynolds, A. J. (1992). Comparing measures of parent involvement and their effects on academic achievement. Early Childhood Research Quarterly, 7, 441-462.

Rogoff, B., Paradise, R., Arauz, R., Correa-Chavez, M., \& Angellilo, C. (2003). Firsthand learning through intent participation. Annual Review of Psychology, 54, $175-203$.

Scribner, J.D., Young, M.D., \& Pedroza, A. (1999). Building collaborative relationships with parents. In J.D. Scribner \& A. Paredes-Scribner (Eds.), Lessons from highperforming Hispanic schools: Creating learning communities (pp. 36-60). New York: Teachers College Press.

Seefeldt, C., Denton, K., Galper, A., \& Younoszai, T. (1998). Former head start parents characteristics, perceptions of school climate, and involvement in their children's education. The Elementary School Journal, 98(4), 340-349.

Sheldon, S. (2002). Parents' social networks and beliefs as predictors of parent involvement. The Elementary School Journal, 102(4), 301-316.

Sheldon, S. (2007). Improving student attendance with school, family, and community partnerships. Journal of Educational Research, 100(5), 267-275.

Shumow, L. \& Lomax, R. (2002). Parental efficacy: Predictor of parenting behavior and adolescent outcomes. Parenting: Science and Practice, 2, 127-150.

Simon, B. (2004). High school and family involvement. Social Psychology of Education, $7(2), 185-209$.

Sobel, M. E. (1982). Asymptotic confidence intervals for indirect effects in structural equation models. Sociological Methodology, Vol. 13, 290-312.

Tan, E.T., \& Goldberg, W.A., (2009). Parental school involvement in relation to children's grades and adaptation to school. Journal of Applied Developmental Psychology, 30(4), 442-453. 
Trumbull, E., Rothstein-Fisch, C., Gieendfield, P.M., \& Quiroz, B. (2001). Bridging cultures between home and school: A guide for teachers. New Jersey: Lawrence Erlbaun Associates.

Trumbull, E., Rothstein-Fisch, C., \& Hernandez, E. (2003). Parent involvement in schooling - According to whose values? The School Community Journal, 13, 4572 .

Valdes, G. (1996). Con respeto: Bridging the distances between culturally diverse families and schools. New York: Teachers College Press.

VanVelsor, P., \& Orozco, G.L. (2007). Involving low-income parents in the schools: communitycentric strategies for school counselors. Professional School Counseling, 11(1), 17-24.

Vygotsky, L. (1978). Mind in Society. Cambridge, MA: Harvard University Press.

Walker, J.M.T., Wilkins, A.S., Dallaire, J.R., Sandler, H.M., \& Hoover-Dempsey, K.V. (2005). Parental involvement: Model revision through scale development. Elementary School Journal, 106, 85-104.

Weiss, H.B., Mayer, E., Kreider, H., Vaughan, M., Dearing, E., Hencke, R., \& Pinto, K. (2003). Making it work: Low-income working mothers' involvement in their children's education. American Educational Research Journal, 40(4), 879-901.

Wong, S.W., \& Hughes, J.N. (2006). Ethnicity and language contributions to dimensions of parent involvement. School Psychology Review, 35(4), 645-662.

Zellman, G.L., \& Waterman, J.M. (1998). Understanding the impact of parent school involvement on children's educational outcomes. Journal of Educational Research, 91, 370-380. 